\title{
PERFORMA PERTUMBUHAN, KOEFISIEN VARIASI, DAN HETEROSIS HASIL PERSILANGAN IKAN PATIN (Pangasius sp.) PADA TAHAP PENDEDERAN II
}

\author{
Jadmiko Darmawan dan Evi Tahapari \\ Balai Riset Pemuliaan Ikan \\ (Naskah diterima: 14 November 2016; Revisi final: 3 April 2017; Disetujui publikasi: 3 April 2017)
}

\begin{abstract}
ABSTRAK
Hibridisasi merupakan salah satu teknik pemuliaan ikan dalam rangka mendapatkan varietas unggul sehingga mampu meningkatkan nilai produksi suatu komoditas ikan yang dibudidayakan. Tujuan penelitian ini adalah untuk mengevaluasi performa pertumbuhan, koefisien variasi, dan nilai heterosis dari hasil persilangan tiga spesies ikan patin sebagai tetua, yaitu patin siam (Pangasianodon hypophthalmus), patin jambal (Pangasius djambal), dan patin nasutus (Pangasius nasutus) pada tahap pendederan II. Induk ikan patin siam dan patin jambal yang digunakan merupakan ikan yang sudah dirilis sebagai ikan budidaya, sedangkan induk ikan patin nasutus berasal dari perairan umum dan sedang dalam proses domestikasi sebagai ikan budidaya. Persilangan yang dibuat adalah: A) $f$ patin jambal $><$ mpatin jambal (J); B)f patin siam $><$ mpatin jambal $(\mathrm{S})$ ); C) f patin siam $><\mathrm{m}$ patin siam (SS); D) $\mathrm{f}$ patin siam $><$ mpatin nasutus (SN); dan E) $f$ patin nasutus $><\mathrm{m}$ patin nasutus (NN). Penelitian dilakukan secara indoor hatchery selama 30 hari pemeliharaan. Nilai heterosis dihitung berdasarkan laju pertumbuhan spesifik (LPS) bobot, LPS panjang total, dan sintasan. Hasil penelitian menunjukkan bahwa performa pertumbuhan, sintasan, dan konversi pakan ikan hasil persilangan tidak berbeda nyata $(P>0,05)$. Ikan patin SN memiliki performa yang lebih baik dari tetuanya dengan nilai heterosis bobot akhir, LPS bobot, panjang total, LPS panjang total, dan sintasan berturut-turut sebesar $110,87 \%$ 19,78\% 36,14\% 36,09\% dan $15,04 \%$ serta nilai koefisien variasi berkisar antara 0,00 11,08. Bobot akhir, panjang total dan sintasan ikan patin SJ juga lebih baik dari tetuanya dengan nilai heterosis berturut-turut sebesar $46,00 \% 11,27 \%$ dan $2,27 \%$ namun untuk heterosis LPS bobot dan LPS panjang total bernilai negatif $(-6,65 \%$ dan $-1,01 \%$, serta nilai koefisien variasi berkisar antara $0,00-12,75$. Berdasarkan hasil penelitian tersebut menunjukkan bahwa ikan patin hibrida SN berpotensi sebagai ikan budidaya dalam rangka peningkatan produksi ikan patin daging putih selain dari ikan patin hibrida SJ (pasupati) yang telah dirilis ke masyarakat.
\end{abstract}

\section{KATA KUNCl: patin; hibrida; hibridisasi; pertumbuhan; dan heterosis}

ABSTRACT: Growth performance, coefficient of variation, and heterosis values from crosses catfish (Pangasius sp.) to segment of seedling II. By: Jadmiko Darmawan and Evi Tahapari

Hybridization is a fish breeding technique in order to obtain high yielding varieties as to increase the production value of a farmed fish. The purpose of this study was to evaluate the growth performance, the coefficient of variation and heterosis value of the result of crossing three species of catfish as a parent, which was striped catfish (Pangasianodon hypophthalmus), jambal catfish (Pangasius djambal) and nasutus catfish (Pangasius nasutus). Crosses made were A) $\mathrm{f}$ jambal catfish $><$ mjambal catfish (J); B) $\mathrm{f}$ striped catfish $><$ mjambal catfish (SJ); C) f striped catfish $><\mathrm{m}$ striped catfish (SS); D) f striped catfish $><$ mnasutus catfish (SN); and E) f nasutus catfish $><$ m nasutus catfish (NN). The study was performed at the indoor hatchery for 30 days. Heterosis values were calculated based on the specific growth rate (SGR) final weight, SGR total length, and survival rate. The results showed that growth performance, survival rate, and feed conversion were not significantly different $(P>0.05)$. Catfish SN has a better performancethan the parent with the value of heter osis at final weight, SGR weight, total length, SGR total length, and survival rate of $110.87 \%, 19.78 \% 36.14 \% 36.09 \%$ and $15.04 \%$ respectively. The coefficient of variation ranged from 0.00 to

\footnotetext{
\# Korespondensi: Balai Riset Pemuliaan Ikan. Jl. Raya 2

Sukamandi Pantura, Patokbeusi 41263, Jawa Barat, Indonesia.

Tel. + (0260) 520500

E-mail: micho_jad@yahoo.co.id
} 
11.08. Final weight, total length, and survival of catfish SJ were also better than the parent with the heterosis value of $46.00 \% 11.27 \%$ and $2.27 \%$ respectively, but for heterosis SGR of the weight and the total length were negative ($6.65 \%$ and $-1.01 \%$ and the coefficient of variation ranged from 0.00 to 12.75 . These results indicated that the hybrid catfish SN has a great potential as fish farming in the hope of increasing the production of white meat catfish hybrid apart from SJ (Pasupati) that have been released to the public.

\section{KEYWORDS: catfish; hybrid; hybridization; growth; and heterosis}

\section{PENDAHULUAN}

Ikan patin merupakan salah satu komoditas unggulan budidaya perairan tawar di Indonesia dan bernilai ekonomis tinggi. Dari 25 jenis ikan patin yang ada, 14 jenis di antaranya terdapat di Indonesia (Gustiano et al., 2003). Pasar ikan patin terbagi atas pasar domestik dan pasar ekspor. Untuk pasar domestik, ikan patin banyak diminati oleh masyarakat di Sumatera dan Kalimantan. Walaupun permintaan pasar ikan patin di kedua wilayah tersebut cukup tinggi, namun permintaan ikan patin terbesar justru dari pasar ekspor. Pasar ekspor ikan patin terbesar adalah untuk kawasan Amerika Serikat dan Eropa. Amerika Serikat mengimpor ikan patin hingga 1,1 juta ton per tahun, terutama dalam bentuk fillet, yang didominasi oleh ikan patin dari Vietnam. Pasar potensial lainnya adalah pasar Eropa (terutama pasar Uni Eropa) yang diperkirakan kebutuhan pasarnya jauh di atas kebutuhan ikan patin di pasar Amerika Serikat. Saat ini 80\%pangsa pasar ikan patin di dunia dan 25\% pangsa pasar ikan patin di pasar Eropa dikuasai oleh Vietnam. Potensi ekspor ikan patin ke pasar Eropa ini makin meningkat dengan dikeluarkannya kebijakan untuk membatasi perburuan ikan cod. Sebagai gantinya, masyarakat Eropa mulai beralih ke ikan patin yang berdaging putih dan memiliki tekstur mirip dengan ikan cod (Anonim, 2013).

Ikan patin daging putih yang selama ini menjadi komoditas andalan Vietnam dalam memenuhi pasar ekspor dikenal dengan nama Pangasius boucourti atau dikenal dengan nama lokal basa. Indonesia juga memiliki beberapa jenis ikan patin berdaging putih, antara lain adalah patin jambal (P. djambal) dan patin nasutus (P. nasutus). Ikan patin jambal dan patin nasutus merupakan ikan asli Indonesia, banyak ditemukan di sungai; Kahayan, Palangkaraya; Kapuas, Sanggau; Barito, Muara Tewe; Batang Hari, Jambi; Musi, Palembang; dan Indragiri, Rengat (Pouyaud et al., 1998). Menurut Gustiano et al. (2003), ikan patin lokal yang memiliki karakter daging putih merupakan spesies yang potensial untuk dikembangkan sebagai salah satu komoditas andalan perikanan budidaya. Namun demikian, dalam pengembangannya terbentur pada penyediaan benih karena fekunditas yang relatif sedikit. Salah satu upaya yang dilakukan untuk mendukung pengembangan patin daging putih tersebut adalah melalui kegiatan hibridisasi (Tahapari et al., 2012).

Ikan patin Siam yang merupakan ikan patin hasil introduksi dari Thailand pada tahun 1972, telah terlebih dahulu berkembang di masyarakat karena mempunyai beberapa keunggulan, antara lain fekunditas yang banyak dan daya tahan yang bagus pada perairan dengan kondisi jelek. Salah satu kekurangan pada spesies ikan patin Siam ini adalah warna daging yang kekuningan sehingga tidak diterima di pasar internasional (Hardjamulia et al., 1987; Arianto \& Utami, 2006).

Dalam rangka mendapatkan varietas ikan patin yang mempunyai kualitas daging putih sesuai permintaan pasar ekspor, memiliki pertumbuhan cepat, dan fekunditas yang banyak perlu diujicoba untuk digabungkan melalui program hibridisasi. Menurut Gjedrem (1993), hibridisasi berarti persilangan antara dua individu yang berbeda yang bertujuan untuk mendapatkan keturunan yang lebih baik. Hibridisasi merupakan salah satu jalan untuk meningkatkan produksi dan dapat juga menghasilkan keturunan atau strain baru, menghasilkan produk yang seragam, serta populasi monoseks (Tave, 1993).

Pemanfaatan teknologi hibridisasi ikan sudah banyak dilakukan antara lain pada ikan tilapia oleh Balai Penelitian Pemuliaan Ikan yang menghasilkan ikan nila hibrida Srikandi yang memiliki pertumbuhan cepat pada salinitas tinggi yang telah dirilis berdasarkan Surat Keputusan Menteri Kelautan dan Perikanan Nomor KEP.09/MEN/2012. Sebelumnya Thien (1993) menghasilkan ikan nila hibrida di Vietnam dengan sintasan, laju pertumbuhan, dan penampilan lebih baik dibandingkan dengan tetuanya. Pada ikan mas (Cyprinus carpio), Kirpichnikov et al. (1993) menghasilkan ikan mas hibrida di Rusia dengan laju pertumbuhan cepat, produktivitas tinggi, dan daya tahan terhadap infeksi penyakit relatif lebih baik, dan Wu (1993) menghasilkan ikan mas hibrida di Cina dengan pertambahan bobot badan 50\%60\% lebih cepat dibandingkan dengan tetuanya, bahkan $100 \%$ lebih cepat dibandingkan dengan ikan mas di alam (wild common carp). Pada ikan patin, sebelumnya telah dilakukan penelitian yang menghasilkan ikan patin hibrida hasil hibridisasi antara patin siam dengan patin jambal (pasupati) yang 
memiliki karakter daging putih dan pertumbuhan yang lebih baik dibandingkan pembentuknya (Gustiano \& Kristanto, 2007; LRPTBPAT, 2006). Ikan patin pasupati telah dirilis berdasarkan Surat Keputusan Menteri Kelautan dan Perikanan Nomor KEP.25/MEN/2006. Iswanto (2011), juga melakukan identifikasi terhadap ikan patin hibrida antara betina patin siam dengan jantan patin nasutus yang memiliki karakter pertumbuhan yang lebih baik dibandingkan pembentuknya. Tahapari (2010) menyatakan bahwa ikan patin hibrida antara betina patin siam dengan jantan patin nasutus memiliki warna fillet yang lebih disukai, kadar air yang lebih rendah, edible portion yang lebih tinggi, dan asam lemak omega 3 yang lebih tinggi dibandingkan dengan ikan patin pasupati.

Penelitian ini dilakukan dengan tujuan untuk mengevaluasi performa pertumbuhan, koefisien variasi, serta mengestimasi nilai heterosis karakter pertumbuhan dan sintasan pada persilangan antar spesies ikan patin nasutus, patin jambal dan patin siam. Pembentukan ikan patin hibrida dapat menjadi alternatif dalam upaya peningkatan produksi ikan patin daging putih yang terjamin kualitas, kuantitas, dan kontinuitas.

\section{BAHAN DAN METODE}

\section{Ikan Uji}

Ikan uji merupakan benih hasil persilangan melalui pemijahan buatan yang dilakukan dengan menggabungkan telur dan sperma dari tiga ekor induk dari masing-masing spesies induk pembentuk, yang selanjutnya dilakukan pemijahan buatan secara massal dengan skema sebagai berikut:
A. JJ :f patin jambal $><$ mpatin jambal
B. SJ : $f$ patin siam $><$ mpatin jambal
C. SS : f patin siam $><$ mpatin siam
D. SN : f patin siam $><$ mpatin nasutus
E. NN : f patin nasutus $><$ mpatin nasutus

Benih ikan uji diperoleh dari hasil pemeliharaan secara indoor hatchery menggunakan bak fiber bulat kapasitas $1.000 \mathrm{~L}$ selama 45 hari. Berdasarkan hasil pengukuran terhadap 30 ekor benih ikan uji diketahui rata-rata bobot awal ikan patin JJ, SJ, SS, SN, dan NN berturut-turut sebesar $0,96 \mathrm{~g} ; 1,57 \mathrm{~g} ; 0,84 \mathrm{~g} ; 1,69 \mathrm{~g}$; dan $1,5 \mathrm{~g}$; serta rata-rata panjang badan awal sebesar $3,97 \mathrm{~cm} ; 4,67 \mathrm{~cm} ; 4,36 \mathrm{~cm} ; 4,97 \mathrm{~cm}$; dan 4,66 cm.

\section{Pemeliharaan Ikan Uji}

Selama pengamatan ikan uji dipelihara menggunakan bak fiber berbentuk kotak dengan kapasitas media pemeliharaan $30 \mathrm{~L}$. Ikan uji ditebar dengan kepadatan 1 ekor/L dan dipelihara selama 30 hari pemeliharaan. Tiap perlakuan dilakukan ulangan pemeliharaan pada tiga wadah yang berbeda. Selama pemeliharaan ikan diberi pakan buatan berbentuk remahan (crumble) dengan kadar protein kasar $40 \%$ Frekuensi pemberian pakan dilakukan lima kali, dengan jumlah pakan yang diberikan (feeding rate/FR) sebanyak $10 \%$ dari biomassa benih.

\section{Parameter Uji}

Monitoring bobot ikan untuk penyesuaian jumlah pakan yang diberikan dilakukan setiap sepuluh hari sekali, sedangkan untuk penghitungan parameter uji digunakan data pada awal saat tebar dan data akhir pada saat benih dipanen (umur benih 30 hari). Monitoring bobot ikan uji dilakukan dengan metode sampling dengan jumlah ikan sampel pada setiap pengamatan sebanyak 30 ekor. Parameter utama yang diamati adalah laju pertumbuhan spesifik (specific growth rate), konversi pakan (feed convertion ratio), sintasan (survival rate), koefisien variasi (coefficient of variation), dan heterosis.

Laju pertumbuhan spesifik dihitung pada berdasarkan rumus Castell \& Tiews (1980):

$$
S G R=\frac{\ln W_{t}-\ln W_{0}}{t} \times 100
$$

di mana:

$W_{t}$ : bobot ikan pada hari ke-t $(g)$

$W_{0}$ : bobot ikan pada awal penelitian (g)

t : waktu pemeliharaan (hari)

SGR: laju pertumbuhan spesifik (\%hari)

Konversi pakan dihitung berdasarkan rumus:

di mana:

$$
F C R=\frac{W_{p}}{\left(W_{t}+D\right)-W_{0}}
$$

FCR: nilai konversi pakan

$\mathrm{W}_{\mathrm{p}}$ : bobot pakan yang diberikan selama pemeliharaan (g)

$\mathrm{W}_{\mathrm{t}}$ : bobot biomassa benih yang dipanen $(\mathrm{g})$

D : bobot biomassa benih yang mati

selama pemeliharaan $(\mathrm{g})$

$\mathrm{W}_{0}$ : bobot biomassa benih yang ditebar $(\mathrm{g})$

Sintasan ikan uji dihitung dengan rumus sebagai berikut:

$$
\mathrm{SR}=\frac{\mathrm{N}_{\mathrm{t}}}{\mathrm{N}_{\mathrm{o}}} \times 100
$$

di mana:

SR : sintasan $(\%$

$N_{t}$ : jumlah pada akhir percobaan (ekor)

$\mathrm{N}_{0}$ : jumlah pada awal percobaan (ekor)

Koefisien variasi ikan uji dihitung dengan rumus Warwick et al. (1995) sebagai berikut:

$$
C V=\frac{S D}{X} \times 100
$$


di mana:

CV : koefisien variasi $(\%$

SD : standar deviasi

$X$ : rata-rata populasi

Parameter yang diamati untuk mengestimasi nilai heterosis populasi hasil persilangan pada akhir pemeliharaan adalah LPS bobot, LPS panjang, konversi pakan, dan sintasan. Nilai heterosis populasi hasil persilangan dihitung menggunakan rumus Tave (1993) sebagai berikut (Tave, 1993):

$$
H=\frac{\left(A B-\left(\frac{A A+B B}{2}\right)\right)}{\left(\frac{A A+B B}{2}\right)}
$$

H : Heterosis

$A B$ : Performa hibrida

$A A$ : Performa tetua betina

BB : Performatetuajantan

Data rata-rata bobot akhir, panjang total, laju pertumbuhan spesifik, konversi pakan, dan sintasan selanjutnya dianalisis dengan menggunakan analisis ragam. Jika dari hasil perhitungan diketahui berbeda nyata, maka dilanjutkan dengan Uji Beda Nyata Terkecil (Uji BNT) dengan selang kepercayaan 95\%(Steel \& Torrie,1991).

\section{HASIL DAN BAHASAN}

Berdasarkan pengamatan pada karakter pertumbuhan, rata-rata bobot akhir tertinggi diperoleh pada populasi ikan patin hasil hibridisasi. Hasil tertinggi diperlihatkan oleh ikan patin hibrida SJ dengan bobot akhir sebesar $21,09 \mathrm{~g}$ dengan laju pertumbuhan spesifik sebesar $9,05 \%$ hari dan panjang total $11,21 \mathrm{~cm}$; disusul oleh hibrida SN dengan bobot akhir sebesar 20,57 g dengan laju pertumbuhan spesifik sebesar $8,69 \%$ hari dan panjang total $11,66 \mathrm{~cm}$. Ikan patin JJ meskipun bobot akhirnya bukanlah yang tertinggi yaitu sebesar 15,63 g; namun memiliki laju pertumbuhan spesifik yang tertinggi, yaitu sebesar 9,75\% /hari; dengan rata-rata panjang sebesar $10,18 \mathrm{~cm}$. Hal ini disebabkan karena bobot awal dari benih ikan patin JJ yang memang lebih rendah dibandingkan ikan patin SS meskipun pada umur pemeliharaan yang sama. Ikan patin NN memiliki karakter pertumbuhan terendah dengan rata-rata bobot akhir sebesar 6,25 $\mathrm{g}$; dengan laju pertumbuhan spesifik sebesar 4,87\% hari dan panjang total sebesar 7,16 g (Tabel 1).

Hasil analisis terhadap nilai konversi pakan dan sintasan menunjukkan hasil yang tidak berbeda nyata antara ikan patin JJ, SJ, SS, dan SN namun berbeda nyata pada ikan patin NN. Kematian pada ikan patin
NN diduga karena tingkat stres yang lebih tinggi pada saat penanganan ketika dilakukan sampling. Susanto (1992) menyatakan kematian ikan dapat terjadi di awal penebaran dan selama pemeliharaan, di antaranya pengaruh dari penangkapan yang menyebabkan ikan stres dan berakhir pada kematian.

Nilai koefisien variasi pada karakter bobot, panjang, dan sintasan tertinggi adalah pada ikan patin SS, yaitu berkisar antara 2,02-25,79; sedangkan nilai koefisien variasi terendah adalah pada ikan patin JJ dan NN yaitu berada pada kisaran 0,00-9,68 dan 0,009,03 . Nilai koefisien variasi pada ikan patin hasil hibridisasi pada karakter bobot, panjang, dan sintasan berada di kisaran kedua tetuanya. Nilai koefisien variasi pada benih ikan patin SJ dan SN berada pada kisaran 0,00-12,75 dan 0,00-11,08. Berdasarkan hasil analisis di atas dapat disimpulkan bahwa secara umum tingkat keragaman genetik ketiga spesies ikan patin dan hasil persilangannya pada karakter bobot, panjang, dan sintasan relatif rendah $(\mathrm{CV}<20 \%$, kecuali ikan patin SS pada karakter bobot (CV> 20\%. Nilai koefisien variasi suatu karakter fenotipe menggambarkan tingkat keragaman karakter fenotipe tersebut pada suatu populasi yang memiliki korelasi positif terhadap keragaman karakter genotipe dan menginterprestasikan keragaman genetik suatu populasi.

Nilai heterosis menerangkan atau menggambarkan suatu kondisi perbandingan antara rata-rata keturunan dengan rata-rata kedua tetuanya, khususnya untuk mengetahui apakah suatu persilangan akan menghasilkan keturunan yang lebih baik atau lebih jelek pada karakter tertentu dibanding dengan tetuanya (Warwick et al., 1990). Nilai heterosis karakter bobot badan, panjang total, laju pertumbuhan spesifik, dan sintasan pada persilangan ikan patin SJ masing-masing sebesar 46,00\% 11,27\% -6,65\% dan 2,27\% Hasil tersebut menunjukkan bahwa heterosis persilangan antara ikan patin JJ dan patin SS pada karakter bobot, panjang, dan sintasan bernilai positif, yang berarti bahwa ikan patin SJ memiliki performa yang lebih baik dibandingkan performa rata-rata kedua tetuanya. Namun untuk heterosis pada karakter laju pertumbuhan spesifik bernilai negatif yang menunjukkan bahwa untuk karakter laju pertumbuhan spesifik ikan SJ memiliki performa yang lebih rendah dibandingkan rata-rata kedua tetuanya. Pada ikan patin SN nilai heterosis karakter bobot badan, panjang total, laju pertumbuhan spesifik dan sintasan masingmasing sebesar $110,87 \% 36,14 \% 19,78 \%$ dan $15,04 \%$ Hasil tersebut menunjukkan bahwa heterosis persilangan antara ikan patin SS dan patin NN pada karakter bobot, panjang, laju pertumbuhan spesifik, dan sintasan bernilai positif, yang berarti bahwa ikan 
Tabel 1. Rata-rata bobot, laju pertumbuhan spesifik bobot, dan koefisien variasi bobot akhir populasi ikan patin hasil pemijahan $\mathrm{f}$ patin jambal $><$ mpatin jambal (J)); f patin siam $><$ mpatin jambal (S)); $f$ patin siam $><$ mpatin siam (SS); $f$ patin siam $><$ mpatin nasutus (SN); $f$ patin nasutus $><$ mpatin nasutus (NN)

Table 1. Average weight, specific growth rate of weight, feed conversion, and coefficient of variation of final weight catfish populations $\mathrm{f}$ jambal catfish $><$ mjambal catfish (J)); $\mathrm{f}$ striped catfish $><\mathrm{m}$ jambal catfish (SJ); f striped catfish $><$ mstriped catfish (SS); f striped catfish $><$ mnasutus catfish (SN); and $\mathrm{f}$ nasutus catfish $><$ mnasutus catfish (NN)

\begin{tabular}{|c|c|c|c|c|}
\hline \multirow{2}{*}{$\begin{array}{c}\text { Populasi } \\
\text { Population }\end{array}$} & \multicolumn{2}{|c|}{ Bobot (Weight) (g) } & \multirow{2}{*}{$\begin{array}{l}\text { Koefisien variasi } \\
\text { bobot akhir } \\
\text { Coefficient of variation } \\
\text { of final weight }\end{array}$} & \multirow{2}{*}{$\begin{array}{l}\text { Laju pertumbuhan } \\
\text { spesifik bobot (\%hari) } \\
\text { Specific growth rate } \\
\text { of weight (\%days) }\end{array}$} \\
\hline & Awal (Initial) & Akhir (Final) & & \\
\hline J & $0.96 \pm 0.09^{a}$ & $15.63 \pm 0.68^{\mathrm{ab}}$ & 4.35 & 9.75 \\
\hline SJ & $1.57 \pm 0.01^{b}$ & $21.09 \pm 3.42^{\mathrm{a}}$ & 12.75 & 9.05 \\
\hline SS & $0.84 \pm 0.08^{a}$ & $13.26 \pm 2.69^{b}$ & 25.79 & 9.63 \\
\hline SN & $1.69 \pm 0.04^{b}$ & $20.57 \pm 2.28^{a}$ & 11.08 & 8.69 \\
\hline NN & $1.5 \pm 0.28^{b}$ & $6.25 \pm 0.20^{c}$ & 3.20 & 4.87 \\
\hline
\end{tabular}

Keterangan (Description): Nilai yang diikuti huruf superskrip yang berbeda pada kolom yang sama menunjukkan nilai berbeda nyata $(P<0,05)$ (Values followed by different superscript letters in the same column indicates values significantly different $(P<0.05))$

Tabel 2. Rata-rata panjang, laju pertumbuhan spesifik panjang, dan koefisien variasi populasi ikan patin hasil pemijahan $\mathrm{f}$ patin jambal $><$ mpatin jambal (JJ); f patin siam $><\mathrm{m}$ patin jambal (SJ); f patin siam $><$ mpatin siam (SS); f patin siam $><$ mpatin nasutus (SN); f patin nasutus $><$ mpatin nasutus (NN)

Table 2. Average length, specific growth rate of length, and coefficient of variation of catfish populations $\mathrm{f}$ jambal catfish $><$ miambal catfish (J)); f striped catfish $><$ miambal catfish (S)); f striped catfish $><$ mstriped catfish (SS); f striped catfish $><$ mnasutus catfish (SN); and $\mathrm{f}$ nasutus catfish $><$ mnasutus catfish (NN)

\begin{tabular}{|c|c|c|c|c|}
\hline \multirow{2}{*}{$\begin{array}{c}\text { Populasi } \\
\text { Population }\end{array}$} & \multicolumn{2}{|c|}{ Panjang (Lenght) $(\mathrm{cm})$} & \multirow{2}{*}{$\begin{array}{l}\text { Koefisien variasi } \\
\text { panjang akhir } \\
\text { Coefficient of variation } \\
\text { of final lenght }\end{array}$} & \multirow{2}{*}{$\begin{array}{l}\text { Laju pertumbuhan } \\
\text { spesifik panjang (\%/hari) } \\
\text { Specific growth rate } \\
\text { of lenght (\%days) }\end{array}$} \\
\hline & Awal (Initial) & Akhir (Final) & & \\
\hline J & $3.97 \pm 0.17^{\mathrm{a}}$ & $10.18 \pm 0.23^{\mathrm{a}}$ & 2.26 & 3.19 \\
\hline SJ & $4.67 \pm 0.08^{\mathrm{a}}$ & $11.21 \pm 1.07^{\mathrm{a}}$ & 3.75 & 2.96 \\
\hline SS & $4.36 \pm 0.16^{\mathrm{a}}$ & $9.97 \pm 0.42^{\mathrm{a}}$ & 10.73 & 2.80 \\
\hline SN & $4.97 \pm 0.05^{\mathrm{a}}$ & $11.66 \pm 0.52^{\mathrm{a}}$ & 4.46 & 2.88 \\
\hline NN & $4.66 \pm 0.28^{\mathrm{a}}$ & $7.16 \pm 0.01^{b}$ & 0.1 & 1.44 \\
\hline
\end{tabular}

Keterangan (Description): Nilai yang diikuti huruf superskrip yang berbeda pada kolom yang sama menunjukkan nilai berbeda nyata $(P<0,05)$ (Values followed by different super script letters in the same column indicates values significantly different $(P<0.05))$

patin SN memiliki performa yang lebih baik dibandingkan performa rata-rata kedua tetuanya. Menurut Noor (2000), persilangan antara dua individu atau populasi yang mempunyai perbedaan genetik dan hubungan kekerabatan yang lebih jauh akan menghasilkan hybrid vigor yang lebih tinggi. Tingginya nilai heterosis pada hasil persilangan ini menunjukkan bahwa jarak genetik dan hubungan kekerabatan di antara spesies tersebut relatif jauh. Kondisi ini sesuai dengan hasil penelitian Arianto \& Utami (2006) yang mendapatkan persilangan antar spesies ikan patin Pangasianodon hypophthalmus dan Pangasius djambal 
Tabel 3. Konversi pakan, sintasan, dan koefisien variasi populasi ikan patin hasil pemijahan $\mathrm{f}$ patin jambal $><$ mpatin jambal (JJ); $\mathrm{f}$ patin siam $><$ m patin jambal (SJ); $\mathrm{f}$ patin siam $><$ mpatin siam (SS); f patin siam $><$ mpatin nasutus (SN); $f$ patin nasutus $><$ mpatin nasutus (NN)

Table 3. Feed conversion ratio, survival rate, and coefficient of variation of catfish populations $f$ jambal catfish $><$ m jambal catfish (JJ); f striped catfish $><$ mjambal catfish (S)); f striped catfish $><$ m striped catfish (SS); f striped catfish $><$ m nasutus catfish (SN); and $f$ nasutus catfish $><\mathrm{m}$ nasutus catfish (NN)

\begin{tabular}{cccc}
\hline $\begin{array}{c}\text { Populasi } \\
\text { Population }\end{array}$ & $\begin{array}{c}\text { Konversi pakan } \\
\text { Feed conversion ratio }\end{array}$ & $\begin{array}{c}\text { Sintasan } \\
\text { Survival rate (\%) }\end{array}$ & $\begin{array}{c}\text { Koefisien variasi panjang akhir } \\
\text { Coefficient of variation of final lenght }\end{array}$ \\
\hline JJ & $0.62 \pm 0.06^{\mathrm{a}}$ & $100 \pm 0.00^{\mathrm{a}}$ & 0.00 \\
SJ & $0.70 \pm 0.07^{\mathrm{a}}$ & $100 \pm 0.00^{\mathrm{a}}$ & 0.00 \\
SS & $0.67 \pm 0.13^{\mathrm{a}}$ & $95.56 \pm 1.93^{\mathrm{a}}$ & 2.02 \\
SN & $0.77 \pm 0.09^{\mathrm{a}}$ & $100 \pm 0.00^{\mathrm{a}}$ & 0.00 \\
NN & $2.19 \pm 0.09^{\mathrm{b}}$ & $78.3 \pm 7.07^{\mathrm{b}}$ & 9.03 \\
\hline
\end{tabular}

Keterangan (Description): $\quad$ Nilai yang diikuti huruf superskrip yang berbeda pada kolom yang sama menunjukkan nilai berbeda nyata $(P<0,05)$ (Values followed by different superscript letters in the same column indicates values significantly different $(P<0.05))$

Tabel 4. Nilai heterosis karakter bobot, panjang total, dan laju pertumbuhan spesifik populasi ikan patin hibrida hasil pemijahan $\mathrm{f}$ patin siam $><$ mpatin jambal (SJ) dan $f$ patin siam $><$ mpatin nasutus (SN)

Table 4. The value of heterosis character of weight, total length, and specific growth rate of hybrid catfish $\mathrm{f}$ striped catfish $><$ miambal catfish (S) and $\mathrm{f}$ striped catfish $><\mathrm{m}$ nasutus catfish (SN)

\begin{tabular}{lcc}
\hline \multirow{1}{*}{$\begin{array}{c}\text { Karakter } \\
\text { Character }\end{array}$} & \multicolumn{2}{c}{$\begin{array}{c}\text { Nilai heterosis } \\
\text { Value of heterosis (\%) }\end{array}$} \\
\cline { 2 - 3 } & SJ & SN \\
\hline $\begin{array}{l}\text { Bobot badan (Body weight) }(\mathrm{g}) \\
\text { Laju pertumbuhan spesifik bobot }\end{array}$ & 46.00 & 110.87 \\
$\begin{array}{l}\text { Specific growth rate of weight }(\mathrm{g}) \\
\text { Panjang total (Total length) }(\mathrm{cm})\end{array}$ & -6.65 & 19.78 \\
$\begin{array}{l}\text { Laju pertumbuhan spesifik panjang } \\
\text { Specific growth rate of length (cm) }\end{array}$ & 11.27 & 36.14 \\
Sintasan (Survival rate) (\%) & -1.01 & 36.09 \\
\hline
\end{tabular}

menghasilkan nilai heterosis pada karakter bobot yang relatif tinggi, yaitu $48,28 \%$ Ariyanto \& Subagyo (2004) menambahkan bahwa hasil yang berbeda ditunjukkan pada persilangan antar galur ikan mas (Cyprinus carpio) dengan nilai heterosis karakter bobot relatif rendah yaitu antara 10,55\%13,48\%

Peningkatan laju pertumbuhan, nilai keragaman genetik, dan tingginya nilai heterosis karakter pertumbuhan pada kegiatan persilangan antar spesies ikan patin akan memberikan peluang keberhasilan yang cukup besar pada kegiatan pemuliaan tersebut (Ariyanto \& Utami, 2006). Hal ini menunjukkan metode hibridisasi atau persilangan merupakan metode pemuliaan yang tepat untuk diterapkan pada kegiatan pemuliaan ikan patin. Sebagaimana digambarkan dari hasil penelitian ini, bahwa ikan patin SN menunjukkan performa yang relatif sama baiknya dengan ikan patin SJ. Dengan demikian, ikan patin SN memiliki potensi yang cukup besar sebagai alternatif dalam peningkatan produksi ikan patin daging putih selain dari ikan patin SJ yang telah dirilis ke masyarakat. 


\section{KESIMPULAN}

Ikan patin hasil hibridisasi dapat menghasilkan ikan patin yang memiliki performa pertumbuhan yang lebih baik dari tetuanya. Ikan patin SN dan SJ memiliki performa pertumbuhan, konversi pakan, dan sintasan yang tidak berbeda nyata antar keduanya, namun ikan patin SN menunjukkan nilai heterosis yang lebih tinggi dibandingkan ikan patin SJ. Ikan patin SN memiliki potensi yang cukup besar sebagai alternatif dalam peningkatan produksi ikan patin daging putih selain dari ikan patin SJ yang telah dirilis ke masyarakat.

\section{UCAPAN TERIMA KASIH}

Penulis menyampaikan rasa terima kasih dan penghargaan yang setulus-tulusnya kepada para teknisi komoditas patin Balai Penelitian Pemuliaan Ikan dan pihak-pihak yang terlibat selama koleksi data maupun dalam penyelesaian makalah ini.

\section{DAFTAR ACUAN}

Anonim. (2013). Pengembangan usaha ikan patin. Ditjen PEN/MJL/004/10/2013. Kementerian Perdagangan RI. Warta Ekspor, hlm. 3-11.

Ariyanto, D., \& Utami, R. (2006). Evaluasi Iaju pertumbuhan, keragaman genetik dan estimasi heterosis pada persilangan antar spesies ikan patin (Pangasius sp.). Jurnal Perikanan (J. Fish. Sci.), VIII(1), 81-86.

Ariyanto, D., \& Subagyo. (2004). Variabilitas genetik dan evaluasi heterosis pada persilangan antar galur dalam spesies ikan mas. Zuriat, 15, 118-124.

Castell, J.D., \& Tiews, K. (1980). Report of the EIFAC, IUNS and ICES working group on the standardization of methodology in fish nutrition recearch. Hamburg. Germany EIFAC Tech. Paper, 24 pp.

Gjedrem, T. (1993). International selective breeding programs: constraints and future prospect. In Selective breeding of fishes in Asia and The United States. Main, K.L., \& Reynolds, E. (Eds.). Proceeding of A workshop in Honolulu. Hawai, May 3-7, 1993, hlm. 18-32.

Gustiano, R., \& Kristanto, A.H. (2007). Evaluation of hibridization between Pangasius djambal Bleeker, 1846 and Pangasianodon hypophthalmus Sauvage, 1878: Biometric characterization and growth analysis. Indonesian Aquaculture Journal, 2(1), 27-33.

Gustiano, R., Sudarto, \& Pouyaud, L. (2003). Bagaimana mengenali patin jambal?. Dalam Slembrouck, J., Komarudin, 0., Maskur, \& Legendre, M. (Eds.). Petunjuk Teknis Pembenihan Ikan Patin Indonesia, Pangasius djambal. IRD-DKP, hlm. 3-14.

Hardjamulia, A., Prihadi, T.H., \& Subagyo. (1987). Pengaruh salinitas terhadap pertumbuhan dan kelangsungan hidup ikan jambal siam (Pangasius sutchi). Bulletin Penelitian Perikanan Darat, 5(1), 111117.

Iswanto, B. (2011). Hibridisasi antara betina patin siam (Pangasianodon hypophthalmus Sauvage, 1878) dengan jantan patin nasutus (Pangasius nasutus Bleeker, 1863) dalam upaya meningkatkan produktivitas patin daging putih. Tesis. Fakultas Perikanan dan IImu Kelautan, Universitas Brawijaya. Malang, $219 \mathrm{hlm}$.

Kirpichnikov, V.S., Ilyasov, J.I., Shart, L.A., Vikhman, A.A., Ganchenko, M.V., Ostashevsky, A.L., Simonov, V.M., Tikhonov, G.F., \& Tjurin, V.V. (1993). Selection of Krasnodar common carp (Cyprinus carpio L.) for resistance to dropsy: Principal, result and prospect. Aquaculture, 111(1-4), 7-20.

Loka Riset Pemuliaan dan Teknologi Budidaya Perikanan Air Tawar [LRPTBPAT]. (2006). Dokumen usulan pelepasan patin hibrida. Sukamandi, $14 \mathrm{hlm}$.

Noor, R.R. (2000). Genetika ternak. Penebar Swadaya. Jakarta, $200 \mathrm{hlm}$.

Pouyoud, L., Gustiano, R., \& Legendre, M. (1998). Phylogenetic relationship among pangasiid catfish species (Siluriformes, Pangasiidae) and new insights on their zoogeography. In Legendre, M., \& Parisele, A. (Eds.). The Biological Diversity and Aquaculture of Clariid and Pangasiid Catfishes in South-East Asia. Proceeding of The Mid-Term Workshop of The Catfish Asia Project. Cantho, Vietnam, 11-15 Mei 1998.

Susanto, W. (1992). Budidaya ikan di pekarangan. Penebar Swadaya. Jakarta, $152 \mathrm{hlm}$.

Steel, R.G.D., \& Torrie, J.H. (1991). Principles and procedures of statistics. London: McGraw-Hill, Book Company, INC., 487 pp.

Tahapari, E., Suryaningrum, D., \& Nurlaela, I. (2010). Penelitian profil sensori hibrida patin daging putih dalam rangka meningkatkan budidaya dan ekspor hasil perikanan. Laporan Teknis Loka Riset Pemuliaan dan Teknologi Budidaya Air Tawar Tahun Anggaran 2010. Loka Riset Pemuliaan dan Teknologi Budidaya Perikanan Air Tawar (LRPTBPAT). Sukamandi, $15 \mathrm{hlm}$.

Tahapari, E., Sularto, \& Nurlaela, I. (2012). Uji multilokasi pemeliharaan ikan patin hibrida nasutus (persilangan betina siam dengan jantan nasutus) di berbagai ekosistem budidaya. Prosiding Indoaqua - Forum Inovasi Teknologi Akuakultur 2012. Pusat Penelitian dan Pengembangan Perikanan Budidaya. Jakarta, hlm. 1045-1053.

Tave, D. (1993). Genetic for fish hatchery managers. The AVI Publ. Comp. inc., NY., USA. 2nd ed., 418 pp. 
Thien, T.M. (1993). A review of the fish breeding research and practices in Vietnam. In Selective breeding of fishes in Asia and The United States. Main, K.L., \& Reynolds, E. (Eds.). Proceeding of A workshop in Honolulu. Hawai, May, 3-7, 1993, p. 190-197.

Warwick, E.J., Astuti, J.M., \& Hardjosubroto, W. (1990). Pemuliaan ternak. Gadjah Mada University Press. Yogyakarta, $485 \mathrm{hlm}$.
Wu, C. (1993). A review of traditional fish selective breeding research and practices in China with emphasis on the use of genetic markers. In Selective breeding of fishes in Asia and The United States. Main, K.L., \& Reynolds, E. (Eds.). Proceeding of A workshop in Honolulu. Hawai, May, 3-7, 1993, p. 206-213. 